\title{
Review on phase change materials and application in building energy saving
}

\author{
Xiangxiang $\mathrm{Wu}^{1 *}$ \\ ${ }^{1}$ Shanghai urban construction vocational college, Shanghai 200438, China
}

\begin{abstract}
Phase change materials (PCMs) can be used for thermal energy storage and temperature regulation during phase change, and have broad application prospects in energy-efficient use and energy saving. The compatibility between traditional phase change materials and building materials is too bad to combine in building energy conservation. Therefore, the new phase change materials have become a research focus in the field of phase change energy storage in buildings. In the paper, the research progress of phase change materials in recent years and the optimization and application of passive building energy-saving are reviewed.
\end{abstract}

\section{Introduction}

The present energy generation from renewable resources does not meet the current global demand for energy supply, which strongly encourages the researchers to switch to safer and cleaner energy usage like sustainable energy resources. Therefore, phase change energy storage technology opens a new window to investigate more on renewable energy resources to fulfill the thermal, electrical, and storage demands[1]. In the building trades, the phase change materials are gradually used as novel construction materials to conserve building energy. In the paper, the characteristics and the application of PCMs in active building energy efficiency were reviewed.

\section{Characteristics of PCMs}

Phase-change energy storage technology is based on PCMs for energy conversion and storage to cut down the energy demand during peak times. Theoretically, substances with suitable phase change temperature and large latent heat can be used as PCMs, however, it is necessary to comprehensively consider stability, supercooling, corrosiveness, safety, and price of PCMs [2]. PCMs selection criteria are presented in Table 1.

Table1. PCMs selection criteria [3].

\begin{tabular}{ccc}
\hline Category & Properties & Criteria \\
\hline & phase change temperature & operated range \\
thermal conductivity & high \\
$\begin{array}{c}\text { Phase-change energy storage } \\
\text { technology is based on PCMs for } \\
\text { energy conversion and storage to } \\
\text { cut down the energy demand } \\
\text { during peak times. }\end{array}$ & specific heat capacity & high \\
& thermal stability & high \\
& phase change equilibrium & high \\
kinetics properties & phase separability & low \\
& density & stable \\
\cline { 2 - 3 } & supercooling & low \\
chemitalization rate & high \\
\cline { 2 - 3 } & reversibility & high \\
economics & stability & high \\
\cline { 2 - 3 } & corrosiveness & low
\end{tabular}

\footnotetext{
*Corresponding author's e-mail: wuxiangxiang@succ.edu.cn
} 


\begin{tabular}{ccc} 
& cost & low \\
\cline { 2 - 3 } & separability & high \\
eco- friendly & recyclability & high \\
& contamination & low \\
\hline
\end{tabular}

The scale of temperature and latent heat in phase change is shown in Figure 1. It shows that phase change temperatures of paraffin waxes, water, and mixtures of water and salt are matched to the temperature range for building energy efficiency so that they are utilized as the most common types of PCMs. Different types of PCMs have different advantages [3-6].

(1) Organic PCMs: high scale of temperature in phase change, high phase transition consistency, with selfnucleation properties, no phase separation, high nucleation rate; high stability, non-hazardous, nonreactive and non-corrosive; high compatibility with conventional structural materials.

(2) Inorganic PCMs: High latent heat, high thermal conductivity, non-combustible, small density change (small volume change during phase change), easily accessible at low cost, eco-friendly.

(3) Eutectic PCMs: high scale of temperature in phase change, high consistency of phase transition, no phase separation.

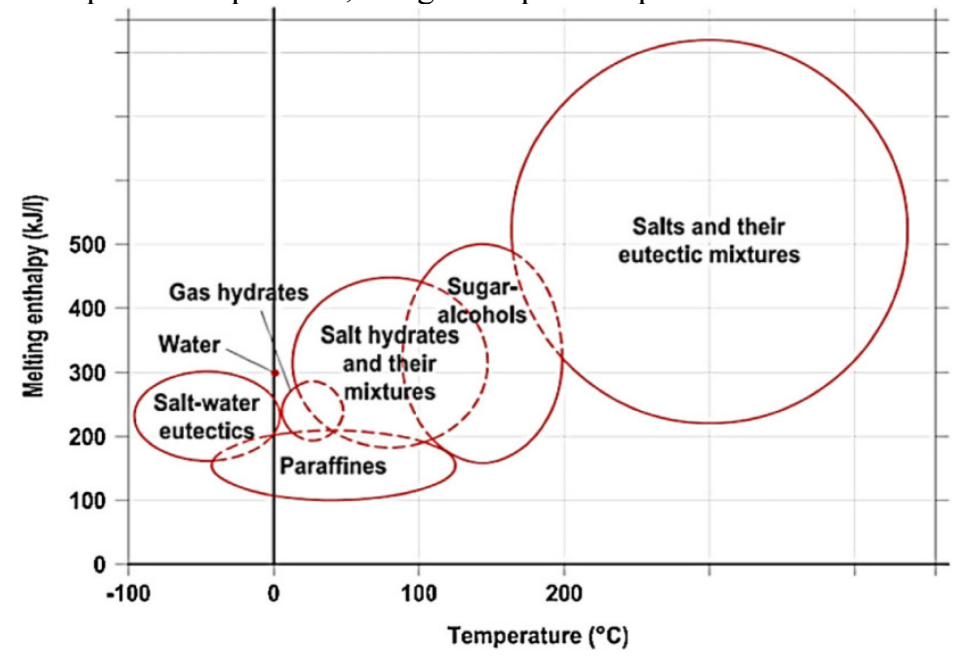

Fig 1. The scale of temperature and latent heat in phase change [7].

\section{Passive Building application}

Thermal energy storage for PCMs has been taken into considerations for the application in buildings with the gradual improvement of building energy consumption standards, and with the concepts and standards of passive buildings and near-zero energy buildings have been proposed. Building energy efficiency measures can be categorized as active or passive, where passive energy efficiency measures refer to a building's ability to resist, reduce or delay external disturbances such as reducing indoor and outdoor heat transfer by using envelope structures. Figure 2 shows the direction of the application of PCMs in active and passive heating systems [8]. Passive energy efficiency measures often combine solar energy with phase-change building materials, using solar energy storage to reduce the solar load and staggering use of solar energy.

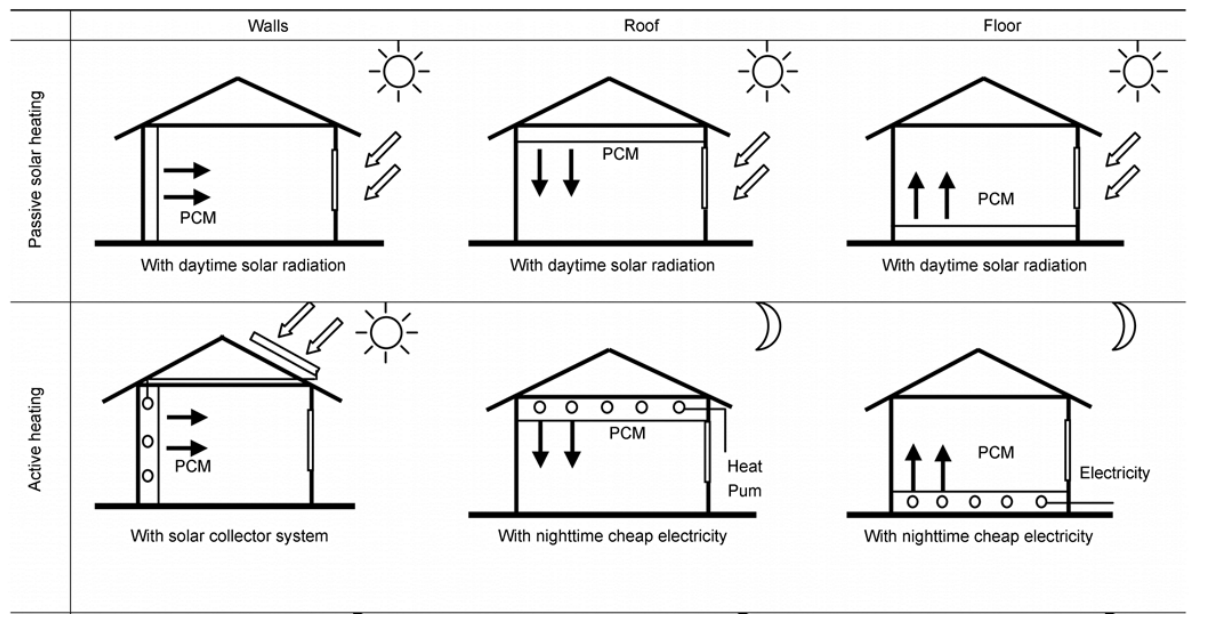

Fig 2. Radiant heating systems using PCMs [8] 
Applying PCMs to walls, windows, roofs, and other building envelopes can change the building's heat load curve, reduce the peak, and even use the outdoor atmosphere as a cold or heat source to provide cooling or heating for the interior, which is an effective way to improve indoor environmental comfort and reduce energy consumption. For example, in winter, the PCM enveloped structure fully stores heat during the day and releases heat at night to bear all or part of the building's heat load at night. Another approach is to use building envelopes containing PCMs to store cold at night in summer to bear the building's cold load during the day. Such PCMs must be well integrated with the building materials, and the PCMs applicable to the building envelope are shown in table 2.

Table2. PCMs for Building

\begin{tabular}{|c|c|c|}
\hline $\begin{array}{l}\text { Phase change } \\
\text { substance }\end{array}$ & Phase change temperature $\left({ }^{\circ} \mathrm{C}\right)$ & Phase change latent heat $(\mathrm{J} / \mathrm{g})$ \\
\hline $\mathrm{C}_{13}-\mathrm{C}_{24}$ & $22 \sim 24$ & 189 \\
\hline $\mathrm{C}_{18}$ & 28 & 244 \\
\hline dodecyl alcohol & $17.5 \sim 22.3$ & 188.8 \\
\hline pungent & 16.5 & 153 \\
\hline sunflower acid & 31.5 & 153 \\
\hline $\mathrm{KF} \cdot 4 \mathrm{H}_{2} \mathrm{O}$ & 18.8 & 231 \\
\hline $\mathrm{CaCl}_{2} \cdot 6 \mathrm{H}_{2} \mathrm{O}$ & 28 & 171 \\
\hline $\mathrm{NaSO}_{4} \cdot 10 \mathrm{H}_{2} \mathrm{O}$ & 32.4 & 254 \\
\hline butyl stearate & $18 \sim 23$ & 140 \\
\hline propyl palmitate & $16 \sim 19$ & 186 \\
\hline
\end{tabular}

New organic composites in building PCMs draw attention currently. Zhang [9] prepared a composite PCM of sodium acetate and area and compared the positions of different PCMs in the external wall insulation based on the integrated discomfort level. The results show that to improve the thermal comfort of the interior, the PCM is preferably placed in the middle of the outer wall. Delcroix [10] used soybean oil and palm oil as PCMs with a phase change temperature of $23^{\circ} \mathrm{C}$. The phase change latent heat is $203 \mathrm{~J} / \mathrm{g}$, which is renewable and biodegradable. The researchers built the test house after adding the PCM to the wall material of the test house through the encapsulation technique, proving that the material is effective in reducing the energy consumption of the building.

Also, phase change building materials are often used in combination with solar energy, where solar radiation during the day is radiated either through collectors or directly in the PCM, providing heat for the building's night time heating. An enclosure consisting of a double-layer PCM was set up in the experimental room to absorb solar energy, as shown in Figure 3 [11]. The experimental study showed that this double-layer PCM increased the satisfaction of indoor thermal comfort conditions from $73 \%$ to $93 \%$ in a dry climate and from $63 \%$ to $75 \%$ in a semiarid climate. The energy consumption for heating was reduced by $17.5 \%$ in a dry climate and $10.4 \%$ in the semiarid climate. Zhang et al. [12] designed a solar heating system with a phase change thermal storage tank, and experiments show that the system can keep the indoor temperature above $20{ }^{\circ} \mathrm{C}$ under the minimum $-10{ }^{\circ} \mathrm{C}$ outdoor conditions. Representative papers on PCMs of passive building were listed in Table 3 .

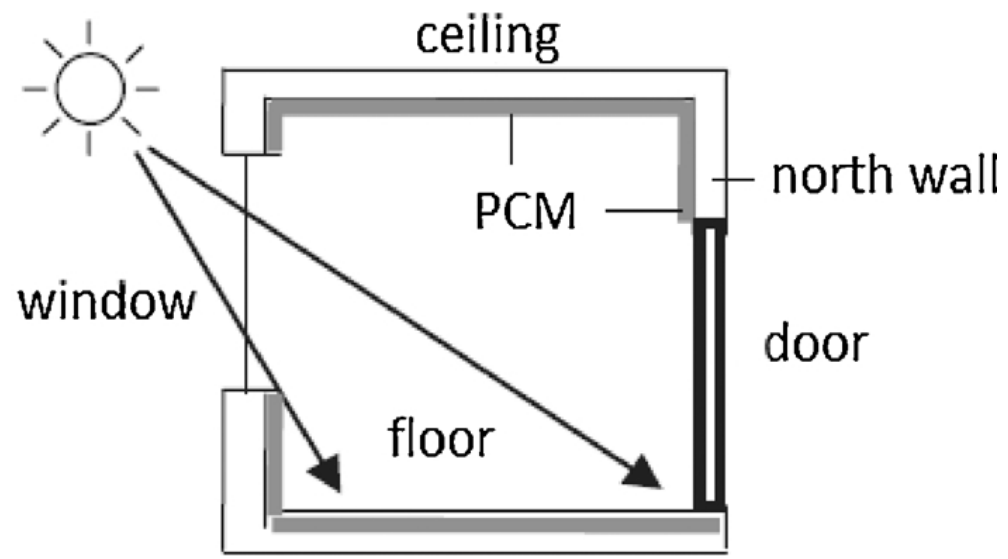

Fig 3. Solar absorbing phase change floor [11] 
Table3. Studies on PCMs in active building energy conservation

\begin{tabular}{|c|c|c|c|c|}
\hline Building Section & Author & PCMs & Time & Features \\
\hline \multirow{4}{*}{ wall } & {$[13]$} & $\begin{array}{l}\text { Microcapsule } \\
\text { d acrylic acid }\end{array}$ & 2007 & $\begin{array}{l}\text { A new PCMs was studied, which was microencapsulated with acrylic } \\
\text { acid and added into concrete to realize energy storage of the wall. The } \\
\text { researchers used this concrete to build a hut in Lecter, Spain }\end{array}$ \\
\hline & {$[14]$} & Acrylic acid & 2012 & $\begin{array}{l}\text { Adding } 25 \% \text { acrylic acid phase change material into the plastering } \\
\text { mortar, the latent heat of the phase change plastering mortar is } 25 \mathrm{~J} / \mathrm{g} \text {, } \\
\text { the phase change temperature is } 23^{\circ} \mathrm{C} \text { to } 25{ }^{\circ} \mathrm{C} \text {, and the thermal } \\
\text { conductivity is } 0.3 \mathrm{~W} / \mathrm{m} 2 \cdot{ }^{\circ} \mathrm{C} \text {. }\end{array}$ \\
\hline & {$[15]$} & Paraffin & 2012 & $\begin{array}{l}\text { The invention relates to an embedded phase change clay brick, in } \\
\text { which paraffin wax is wrapped and embedded into a hollow clay brick }\end{array}$ \\
\hline & {$[16]$} & $\begin{array}{l}\text { Fatty acid, } \\
\text { paraffin and saline }\end{array}$ & 2011 & With glass brick as the shell material, \\
\hline \multirow{2}{*}{ Window } & {$[17]$} & $\begin{array}{l}\text { Calcium } \\
\text { chloride }\end{array}$ & 2017 & $\begin{array}{l}\text { The heat storage properties of three kinds of phase change materials, } \\
\text { fatty acid, paraffin and saline, were compared }\end{array}$ \\
\hline & {$[18]$} & $\begin{array}{l}\text { Paraffin with } \\
\text { nano-particles }\end{array}$ & 2020 & $\begin{array}{l}\text { The paraffin wax mixed with } \mathrm{Al} 2 \mathrm{O} 3, \mathrm{TiO} 2 \text { and } \mathrm{ZnO} \text { nanoparticles was } \\
\text { added into the double-layer glass }\end{array}$ \\
\hline \multirow{2}{*}{ Roof/Ceiling } & {$[19]$} & $\begin{array}{l}\text { Polyurethane } \\
\text { with parafiin }\end{array}$ & 2020 & $\begin{array}{l}\text { The influence of paraffin content of } 15 \%, 25 \% \text { and } 35 \% \text { on } \\
\text { waterproofing and thermal stability of polyurethane roofing was } \\
\text { studied }\end{array}$ \\
\hline & {$[20]$} & Paraffin wax & 2019 & $\begin{array}{l}\text { A wood-plastic board roofing material embedded with phase change } \\
\text { material (paraffin wax) was developed }\end{array}$ \\
\hline Floor & {$[21]$} & $\begin{array}{l}\text { Eutectic fatty } \\
\text { acids }\end{array}$ & 2018 & $\begin{array}{l}\text { A floor made of a mixture of eutectic fatty acids as phase change } \\
\text { materials }\end{array}$ \\
\hline
\end{tabular}

\section{Conclusion}

Current studies are mainly focused on the phase transition temperature and latent heat of phase transition of PCMs, with other thermophysical parameters less studied. The optimization of the overall properties of PCMs is the highest potential direction of further study. For instance, the organic PCMs have no subcooling and phase separation but with low thermal conductivity. The inorganic PCMs have strong thermal conductivity and heat storage capacity, and more studies will be needed on their suitable nucleating agent and anti-supercooling agent to optimize its phase-change performance. The phase transition temperature of eutectic PCMs can be controlled by changing the mass fraction of each component, and more studies will be needed on the improvement of their latent heat of phase change and specific heat capacity. Furthermore, to provide a viable means of improving energy efficiency, more focuses are also needed on the development of more simplified processes, reduced costs and promoted application to more occasions.

\section{Reference}

1. Zhai, X., Wang, X., Wang, T. et al. (2013) A review on phase change cold storage in air-conditioning system: Materials and applications. Renewable \& Sustainable Energy Reviews, 22: 108-120.

2. Yu, H. (2009) Air-conditioning refrigeration technology and design. Science Press. Beijing.

3. Soares, N., Costa, J., Gaspar, A. et al. (2013) Review of passive PCM latent heat thermal energy storage systems towards buildings' energy efficiency. Energy and Buildings, 59: 82-103.
4. Kenisarin, M., Mahkamov, K. (2007) Solar energy storage using phase change materials. Renewable and Sustainable Energy Reviews, 11: 1913-1965.

5. Sharma, A., Tyagi, V. V., Chen, C. R. et al. (2009) Review on thermal energy storage with phase change materials and applications. Renewable and Sustainable Energy Reviews, 13: 318-345.

6. Zhang, G.J., Wang, Z. M., Li, D. et al. (2020) Seasonal thermal performance analysis of glazed window filled with paraffin including various nanoparticles. International Journal of Energy Research, 44: 3008-3019.

7. Souayfane, F., Fardoun, F., Biwole, P. et al. (2016) Phase change materials (PCM) for cooling applications in buildings: A review. Energy and Buildings, 129: 396-431.

8. Wang, X., Zhang, Y. P., Xiao, W. et al. (2009) Review on thermal performance of phase change energy storage building envelope. Chinese Science Bulletin, 54: 920-928.

9. Zhang, Y., Wang, X., Wei, Z. (2018) Sodium acetateurea composite phase change material used in building envelopes for thermal insulation. Building Services Engineering Research \& Technology, 39(4):475-491.

10. Delcroix, B. Kummert, M. Daoud, A. (2017) Building-scale experimental validation of a new model for walls with phase change materials. Sci. Technol. Built Environ., 23: 1049-1062.

11. Ahangari, M., Maerefat, M. (2019) An innovative PCM system for thermal comfort improvement and energy demand reduction in building under different climate conditions. Sustainable Cities and Society, 44: 120-129. 
12. Zhang, X., Xu, C. T. et al. (2019) Application Study on Solar Heating System. Energy Conservation Technology, (37):4

13. Cabeza, L F, Cecilia, C., Miquel, N., et al. (2007) Use of microencapsulated PCM in concrete walls for energy savings. Energy and Buildings, 39(2):113-119

14. Sá, A. V., Azenha ,M., de, S. H., et al. (2012) Thermal enhancement of plastering mortars with Phase Change Materials:Experimental and numerical approach. Energy and Buildings, 49:16-27

15. Silva, T., Vicente, R., Soares, N., et al. (2012) Experimental testing and numerical modelling of masonry wall solution with PCM incorporation:A passive construction solution. Energy and Buildings, 49:235-245

16. Bontemps, A., Ahmad, M., Johannès, K., et al. (2011) Experimental and modelling study of twin cells with latent heat storage walls. Energy and Buildings, 43(9):2456-2461

17. Kolacek, M. (2017) Measurement of four-pane building window filled with a PCM. MATEC Web of Conferences, 125:02019

18. Zhang, G., Wang, Z., Li, D., et al. (2020) Seasonal thermal performance analysis of glazed window filled with paraffin including various nanoparticles. International Journal of Energy Research:1-12

19. Fabiani, C., Piselli, C., Pisello, A. L. (2020) Thermooptic durability of cool roof membranes: Effect of shape stabilized phase change material inclusion on building energy efficiency. Energy and Buildings, 207:109592

20. Yang, Y. K., Kim, M. Y., Chung, M. H., et al. (2019) PCM cool roof systems for mitigating urban heat island - an experimental and numerical analysis. Energy and Buildings, 205:109537

21. Xing, J. C., Zhou, Y. C., Yu, Y. X., et al. (2018) Simulation of storage and heat release performance of fatty acid phase change floor for ground heating. Scientia Forestry, 54(11):23-31 